\title{
Improved Synthetic Route to Methyl 1-Fluoroindan-1-carboxylate (FICA Me Ester) and 4-Methyl Derivatives
}

\author{
Jyunichi Koyanagi, Tomoyo Kamei, Miyuki Ishizaki, Hiroshi Nakamura, and Tamiko Takahashi* \\ Faculty of Pharmaceutical Sciences, Josai International University; 1 Gumyo, Togane, Chiba 283-8555, Japan. \\ Received February 27, 2014; accepted May 23, 2014; advance publication released online June 10, 2014
}

An improved synthetic route has been developed for the preparation of methyl 1-fluoroindan-1-carboxylate (FICA Me ester) from 1-indanone. Methyl 4-methyl-1-fluoroindan-1-carboxylate (4-Me-FICA Me ester) was also prepared following the same procedure.

Key words chiral derivatizing agent; methyl 1-fluoroindan-1-carboxylate; fluorination

We have developed an improved synthetic strategy for the synthesis of 1-fluoroindan-1-carboxylic acid (FICA) (1), which can be used as a chiral derivatizing agent (CDA) for determining the absolute configuration of chiral secondary alcohols (Chart 1).

FICA (1) has been reported to be superior to $\alpha$-methoxy- $\alpha$ (trifluoromethyl)phenylacetic acid (MTPA) with respect to its use as a CDA for determining the absolute configurations of chiral secondary alcohols using ${ }^{19} \mathrm{~F}$ - and ${ }^{1} \mathrm{H}-\mathrm{NMR}$ spectroscopy. ${ }^{1,2)}$ However, contrary to our expectations, the $\Delta \delta_{\mathrm{H}}\left(\delta_{R}-\right.$ $\delta_{S}$ ) values of FICA esters were found to be similar to those of MTPA esters. The FICA esters of chiral alcohols are originally formed by the transesterification of FICA Me ester with the chiral alcohol of interest. Unfortunately, the FICA esters of chiral alcohols cannot be formed under Schotten-Baumann reaction conditions using the FICA chloride because FICA is unstable under these conditions. On the other hand, conformational studies of MPA (methoxyphenylacetic acid) as a CDA were revealed that the introduction of substituents on the benzene ring shifts the equilibrium between the synperiplanar $(s p)$ and antiperiplanar (ap) conformers. ${ }^{3)}$ Thus, we expected that the introduction of substituents on the benzene ring moiety of FICA may affect the ability of FICA as a CDA. As part of our ongoing research towards the development of new and improved CDAs, we recently investigated the preparation of FICA derivatives bearing substituents on the benzene ring moiety with the aim of improving their effectiveness as CDA and the overall stability of FICA.

\section{Results and Discussion}

The aim of the current study was to develop a new and improved synthetic route to FICA Me ester (2) that incorporated the following features: (i) the procedure would start from 1-indanone (3) because a large number of 1-indanone derivatives bearing a range of different substituents on the benzene ring are commercially available; and (ii) all of the reactions involved in the synthesis would be simple and avoid the use of exotic reagents and materials.

With these requirements in mind, we developed the synthetic route shown in Chart 2. Briefly, the Wittig reaction of 1-indanone (3) with methyltriphenylphosphonium bromide gave the exo-methylene 4, together with a small amount of the corresponding endo-methylene compound. The Wittig reaction mixture was treated directly with osmium oxide, immobilized catalyst I (Os IC-I) in the presence of $N$-methylmorpholine $N$ oxide (NMO) to yield diol $\mathbf{5},{ }^{4)}$ which was subjected to an airmediated oxidation reaction using a platinum carbon catalyst to give $\alpha$-hydroxycarboxylic acid 6. ${ }^{5)}$ Disappointingly, treatment of $\mathbf{6}$ with (diethylamino)sulfur trifluoride (DAST) gave 1-indanone (3) and none of the target FICA (1). The formation of 1-indanone (3) in this case was attributed to the fluoride ion-mediated decarboxylation of $6^{6)}$ (Chart 2).

To prevent this decarboxylation pathway, $\alpha$-hydroxycarboxylic acid 6 was converted to the corresponding methyl ester 7 using Blanchfield's method.' ${ }^{7)}$ The ester 7 was then fluorinated using bis(2-methoxyethyl)aminosulfur trifluoride (Deoxo-Fluor) instead of DAST because Deoxo-Fluor is more thermally stable than DAST and can be handled at room temperature. ${ }^{8)}$ The reaction of the ester 7 with Deoxo-Fluor gave FICA methyl ester (2) in $83 \%$ yield. The yield was similar to that reported for the previous method using DAST. ${ }^{1)}$ The total yield of this route $(36 \%)$ was lower than that of the previous method $(52 \%){ }^{1)}$ However this process did not require any exotic or complicated reagents and techniques.

One of the key features of this improved method is that it could be used for the synthesis of FICA derivatives bearing a variety of different substituents on their benzene ring moiety. To demonstrate the utility of this feature, we completed the synthesis of methyl 4-methyl-1-fluoroindan-1-carboxylate (4-Me-FICA Me ester) (8) starting with commercially available 4-methyl-1-indanone (9). Briefly, the olefination of 9 with methyltriphenylphosphonium bromide gave the exo-methylene 10, which was dihydroxylated to give diol $\mathbf{1 1}$ in good yield. Subsequent oxidation of $\mathbf{1 1}$ gave $\alpha$-hydroxycarboxylic acid 12, which was converted to the corresponding methyl ester 13 using Blanchfield's method.' The ester 13 was then fluorinated in the same way as 7 to give 4-Me-FICA Me ester (8). 4-Me-FICA Me ester (8) was obtained totally in 35\% yield from 4-methyl-1-indanone (9).

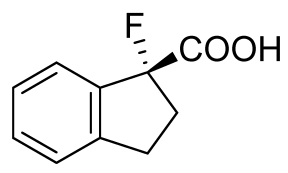

1: $(R)-$ FICA

Chart 1

The authors declare no conflict of interest. 


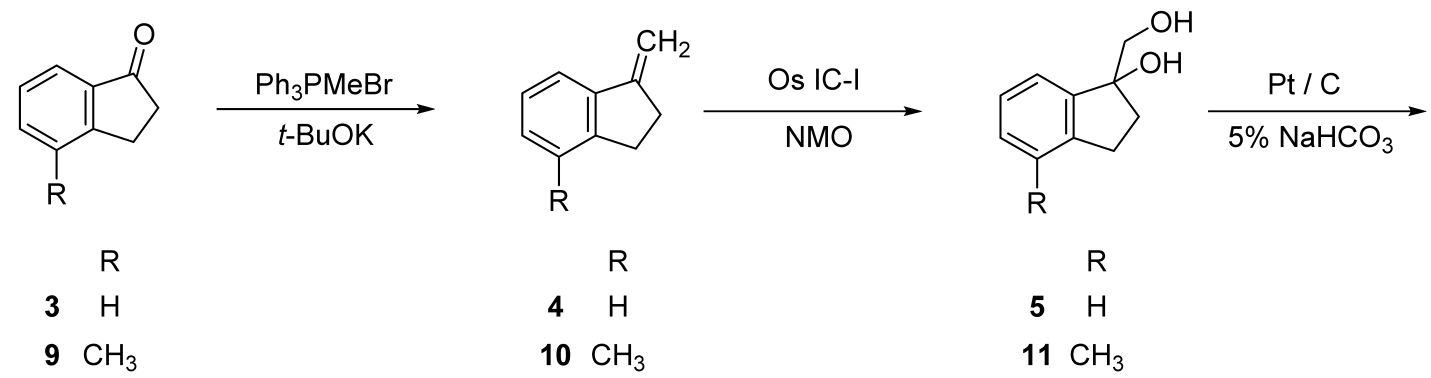<smiles>[R]CC(C)CC(CC(=O)OC)C(=O)O</smiles><smiles>CCN[O+]OCC1(C(=O)O[Al-]C(C)C)CCc2ccccc21</smiles><smiles>[R]c1cccc2c1CCC2(O)C(C)=O</smiles><smiles>[R]c1cccc2c1CCC2(F)C(C)=O</smiles>

Chart 2

\section{Conclusion}

In conclusion, we have developed an improved and simple route for the synthesis of FICA methyl ester (2) that does not require any exotic or complicated reagents and techniques. Furthermore, we have shown that our newly developed procedure can be used for the synthesis of FICA derivatives bearing substituents on the benzene ring moiety starting from commercially available 1-indanone derivatives. For example, using our newly developed method, we successfully prepared 4-Me-FICA Me ester (8) from 4-methyl-1-indanone (9). Further studies are currently underway in our laboratory towards the preparation of FICA derivatives bearing halogen substituents on the benzene ring moiety, and the evaluation of these compounds as CDAs. We are also involved in investigating the conversion of these compounds to the corresponding acyl chlorides.

\section{Experimental}

General Melting points were measured with a Yanaco micro melting point apparatus and are uncorrected. Microanalyses were performed by Microanalysis Center of Josai University. Spectroscopic measurements were carried out with the following instruments: IR, JASCO FT/IR-4200; MS, JEOL JMS-700; high resolution-mass spectra (HR-MS), JEOL JMS-700; ${ }^{1} \mathrm{H}-\mathrm{NMR}$, JEOL ECA $500(500 \mathrm{MHz})$ for solutions in $\mathrm{CDCl}_{3}$ with $\mathrm{Me}_{4} \mathrm{Si}$ as an internal standard; ${ }^{13} \mathrm{C}$-NMR, JEOL ECA $500(125 \mathrm{MHz})$ for solutions in $\mathrm{CDCl}_{3}$ with $\mathrm{Me}_{4} \mathrm{Si}$ as an internal standard; ${ }^{19} \mathrm{~F}-\mathrm{NMR}$, JEOL ECA $500(470 \mathrm{MHz})$ for solutions in $\mathrm{CDCl}_{3}$ with $\mathrm{CFCl}_{3}$ as an internal standard. Os IC-I was purchased from Wako Pure Chemical Industries, Ltd. (Osaka, Japan).
1-Methylene-2,3-dihydro-1 $\boldsymbol{H}$-indene (4) To a solution of 1-indanone (3) (1.0 g, 7.6 mmol) and $\mathrm{Ph}_{3} \mathrm{PMeBr} \quad(5.4 \mathrm{~g}$, $15.1 \mathrm{mmol})$ in dry tetrahydrofuran (THF) $(50 \mathrm{~mL})$ was added tert-BuOK $(1.7 \mathrm{~g}, 15.1 \mathrm{mmol})$ in dry THF $(50 \mathrm{~mL})$ over a period of $1 \mathrm{~h}$ under nitrogen atmosphere at room temperature. After being stirred at room temperature for $1 \mathrm{~h}$, half amount of THF was evaporated. To the residue was added $\mathrm{H}_{2} \mathrm{O}(100 \mathrm{~mL})$ and the aqueous layer was extracted with $\mathrm{Et}_{2} \mathrm{O}(50 \mathrm{~mL} \times 3)$. The organic layer was washed with brine and dried over $\mathrm{Na}_{2} \mathrm{SO}_{4}$. The solvent was evaporated and the residue was purified by column chromatography (hexane) to give the exo-methylene compound $4(0.81 \mathrm{~g}, 6.2 \mathrm{mmol}, 82 \%)$ as a colorless oil. This compound 4 was subjected to the next reaction without further purification; ${ }^{1} \mathrm{H}-\mathrm{NMR}\left(500 \mathrm{MHz}, \mathrm{CDCl}_{3}\right) \delta: 2.79$ (2H, m), 2.97 $(2 \mathrm{H}, \mathrm{m}), 5.03(1 \mathrm{H}, \mathrm{t}, J=2.3 \mathrm{~Hz}), 5.44(1 \mathrm{H}, \mathrm{t}, J=2.3 \mathrm{~Hz}), 7.20$ $(2 \mathrm{H}, \mathrm{m}), 7.25(1 \mathrm{H}, \mathrm{m}), 7.49(1 \mathrm{H}, \mathrm{dd}, J=3.4,6.3 \mathrm{~Hz}) ;{ }^{13} \mathrm{C}-\mathrm{NMR}$ $\left(125 \mathrm{MHz}, \mathrm{CDCl}_{3}\right) \delta: 30.1,31.1,102.4,120.6,125.3,126.4$, 128.2, 141.0, 146.7, 150.5.

1-(Hydroxymethyl)-2,3-dihydro-1H-inden-1-ol (5) To a mixture of exo-methylene compound $4(0.50 \mathrm{~g}, 3.8 \mathrm{mmol})$ and $\mathrm{NMO}(0.68 \mathrm{~g}, 5.8 \mathrm{mmol})$ in $\mathrm{CH}_{3} \mathrm{CN}$-acetone- $\mathrm{H}_{2} \mathrm{O}(1: 1: 1$, $15 \mathrm{~mL})$ was added Os IC-I $\left(0.70 \mathrm{~g}, \mathrm{OsO}_{4} 0.19 \mathrm{mmol}\right)$ at room temperature. After being stirred at room temperature for $18 \mathrm{~h}$, Os IC-I was removed by filtration. Os IC-I was washed with $\mathrm{H}_{2} \mathrm{O}(10 \mathrm{~mL} \times 3)$ and then AcOEt $(10 \mathrm{~mL} \times 3)$. The washed solvents were added to the filtrate. The mixed solution was extracted with AcOEt $(30 \mathrm{~mL} \times 3)$. The organic layer was washed with brine and dried over $\mathrm{Na}_{2} \mathrm{SO}_{4}$. The solvent was evaporated and the residue was purified by column chromatography (hexane-AcOEt $=1: 4)$ to give the diol $5(0.55 \mathrm{~g}, 3.3 \mathrm{mmol}, 88 \%)$ as a colorless oil; IR (neat) $3353(\mathrm{OH}), 2936(\mathrm{CH}) \mathrm{cm}^{-1}$; ${ }^{1} \mathrm{H}-\mathrm{NMR}$ 
$\left(500 \mathrm{MHz}, \mathrm{CDCl}_{3}\right) \delta: 2.07(1 \mathrm{H}, \mathrm{dt}, J=8.6,13 \mathrm{~Hz}), 2.45(1 \mathrm{H}$, ddd, $J=3.5,8.0,13 \mathrm{~Hz}), 2.85(1 \mathrm{H}, \mathrm{dt}, J=8.0,16 \mathrm{~Hz}), 3.03(1 \mathrm{H}$, ddd, $J=3.5,8.6,16 \mathrm{~Hz}), 3.30(1 \mathrm{H}, \mathrm{brs}), 3.65(2 \mathrm{H}, \mathrm{d}, J=12 \mathrm{~Hz})$, $3.74(1 \mathrm{H}, \mathrm{d}, J=12 \mathrm{~Hz}), 7.25(1 \mathrm{H}, \mathrm{t}, J=7.5 \mathrm{~Hz}), 7.26(1 \mathrm{H}, \mathrm{d}$, $J=7.5 \mathrm{~Hz}), 7.29(1 \mathrm{H}, \mathrm{t}, J=7.5 \mathrm{~Hz}), 7.40(1 \mathrm{H}, \mathrm{d}, J=7.5 \mathrm{~Hz})$; ${ }^{13} \mathrm{C}-\mathrm{NMR}\left(125 \mathrm{MHz}, \mathrm{CDCl}_{3}\right) \delta: 29.2,36.8,67.7,83.7,123.4$, $124.9,126.6,128.5,143.3,144.5$; MS $m / z: 164\left(\mathrm{M}^{+}\right), 133([\mathrm{M}-$ $\left.\mathrm{CH}_{2} \mathrm{OH}\right]^{+}$), 115 (indenyl cation); HR-MS Calcd for $\mathrm{C}_{10} \mathrm{H}_{12} \mathrm{O}_{2}$ $\left(\mathrm{M}^{+}\right)$: 164.0837, Found: 164.0810.

1-Hydroxy-2,3-dihydro-1 $H$-indene-1-carboxylic Acid (6) A suspension of the diol 5 (0.55 g, $3.4 \mathrm{mmol}), 5 \% \mathrm{Pt} / \mathrm{C}(0.31 \mathrm{~g})$, $\mathrm{NaHCO}_{3}(0.63 \mathrm{~g}, 7.5 \mathrm{mmol})$ in $\mathrm{H}_{2} \mathrm{O}(5 \mathrm{~mL})$ was stirred at $70^{\circ} \mathrm{C}$. Oxygen gas was introduced into the reaction mixture for $48 \mathrm{~h}$. The mixture was filtered through a celite pad. The filtrate was washed with AcOEt to remove non-acidic compound. The aqueous layer was acidified with $2 \mathrm{~mol} / \mathrm{L} \mathrm{H}_{2} \mathrm{SO}_{4}$ to $\mathrm{pH} 2$. Then the acidic solution was extracted with AcOEt $(10 \mathrm{~mL} \times 3)$. The organic layer was washed with brine and dried over $\mathrm{Na}_{2} \mathrm{SO}_{4}$. The solvent was evaporated and the residue was purified by column chromatography (hexane-AcOEt=3:7) to give the hydroxycarboxylic acid $6(0.50 \mathrm{~g}, 8.4 \mathrm{mmol}, 83 \%)$ as a colorless oil; IR (neat) $3415(\mathrm{OH}), 2946(\mathrm{CH}), 1709(\mathrm{C}=\mathrm{O}) \mathrm{cm}^{-1}$; ${ }^{1} \mathrm{H}-\mathrm{NMR}\left(500 \mathrm{MHz}, \mathrm{CDCl}_{3}\right) \delta: 2.30(1 \mathrm{H}, \mathrm{m}), 2.76(1 \mathrm{H}, \mathrm{m})$, $3.12(2 \mathrm{H}, \mathrm{m}), 7.23(1 \mathrm{H}, \mathrm{m}), 7.31(3 \mathrm{H}, \mathrm{m}) ;{ }^{13} \mathrm{C}-\mathrm{NMR}(125 \mathrm{MHz}$, $\left.\mathrm{CDCl}_{3}\right) \delta: 30.3,38.6,83.7,123.0,125.1,126.9,129.3,142.7$, 144.0, 179.5; MS m/z: $178\left(\mathrm{M}^{+}\right), 133\left([\mathrm{M}-\mathrm{COOH}]^{+}\right), 115$ (indenyl cation); HR-MS Calcd for $\mathrm{C}_{10} \mathrm{H}_{10} \mathrm{O}_{3}\left(\mathrm{M}^{+}\right)$: 178.0630, Found: 178.0602.

Fluorination of the Hydroxycarboxylic Acid 6 by DAST To a solution of hydroxycarboxylic acid $6(0.11 \mathrm{~g}, 0.62 \mathrm{mmol})$ in dry $\mathrm{CH}_{2} \mathrm{Cl}_{2}(10 \mathrm{~mL})$, DAST $(0.20 \mathrm{~g} 1.24 \mathrm{mmol})$ in dry $\mathrm{CH}_{2} \mathrm{Cl}_{2}(10 \mathrm{~mL})$ was added slowly at $-78^{\circ} \mathrm{C}$ under nitrogen atmosphere. The reaction mixture was warmed to room temperature and stirred for $4.5 \mathrm{~h}$. To the reaction mixture, $\mathrm{H}_{2} \mathrm{O}$ $(2 \mathrm{~mL})$ was added carefully. The solution was extracted with $\mathrm{CH}_{2} \mathrm{Cl}_{2}(5 \mathrm{~mL} \times 2)$. The organic layer was washed with brine and dried over $\mathrm{Na}_{2} \mathrm{SO}_{4}$. The solvent was evaporated and the residue was purified by column chromatography (hexane$\mathrm{AcOEt}=9: 1)$ to give the product $3(30 \mathrm{mg}, 0.23 \mathrm{mmol}, 37 \%)$ as a colorless power. The structure of the product $\mathbf{3}$ was confirmed by comparing its NMR data with those of commercially available 1-indanone.

Methyl 1-Hydroxy-2,3-dihydro-1 $H$-indene-1-carboxylate (7) To a solution of the acid $6(0.21 \mathrm{~g}, 1.2 \mathrm{mmol})$ in $\mathrm{MeOH}$ ( $7 \mathrm{~mL}$ ) was added $\mathrm{H}_{3} \mathrm{BO}_{3}(22 \mathrm{mg}, 0.35 \mathrm{mmol})$ at room temperature. After being stirred at room temperature for $66 \mathrm{~h}$, saturated aqueous $\mathrm{NaHCO}_{3}$ solution $(5 \mathrm{~mL})$ and $\mathrm{H}_{2} \mathrm{O}(10 \mathrm{~mL})$ were added to the reaction mixture. The solution was extracted with AcOEt $(20 \mathrm{~mL} \times 3)$. The organic layer was washed with brine and dried over $\mathrm{Na}_{2} \mathrm{SO}_{4}$. The solvent was evaporated and the residue was purified by column chromatography (hexane$\mathrm{AcOEt}=7: 3)$ to give the ester $7(0.16 \mathrm{~g}, 0.86 \mathrm{mmol}, 73 \%)$ as a colorless oil; the structure of 7 was confirmed by comparing its NMR data with those obtained previously. ${ }^{1)}$

Methyl 1-Fluoroindan-1-carboxylate (2) (FICA Me Ester) To a solution of the ester $7(0.16 \mathrm{~g}, 0.86 \mathrm{mmol})$ in dry $\mathrm{CH}_{2} \mathrm{Cl}_{2}$ $(4 \mathrm{~mL})$ was added slowly Deoxo-fluor $(0.57 \mathrm{~g}, 2.57 \mathrm{mmol})$ in dry $\mathrm{CH}_{2} \mathrm{Cl}_{2}(8 \mathrm{~mL})$ at room temperature under nitrogen atmosphere. After being stirred at room temperature for $40 \mathrm{~min}$, saturated aqueous $\mathrm{NaHCO}_{3}$ solution $(6 \mathrm{~mL})$ and $\mathrm{H}_{2} \mathrm{O}(6 \mathrm{~mL})$ were added to the reaction mixture. The solution was extract- ed with $\mathrm{CH}_{2} \mathrm{Cl}_{2}(10 \mathrm{~mL})$. The organic layer was washed with brine and dried over $\mathrm{Na}_{2} \mathrm{SO}_{4}$. The solvent was evaporated and the residue was purified by column chromatography (hexane$\mathrm{AcOEt}=9: 1)$ to give the fluoroester $2(0.14 \mathrm{~g}, 0.71 \mathrm{mmol}, 83 \%)$ as a yellow oil; the structure of $\mathbf{2}$ was confirmed by comparing its NMR data with those obtained previously. ${ }^{1)}$

4-Methyl-1-methylene-2,3-dihydro-1H-indene (10) To a solution of 4-methyl-1-indanone (9) (1.0 g, 6.8 mmol) and $\mathrm{Ph}_{3} \mathrm{PMeBr}(4.9 \mathrm{~g}, 13.7 \mathrm{mmol})$ in dry THF $(50 \mathrm{~mL})$ was added tert-BuOK $(1.5 \mathrm{~g}, 13.4 \mathrm{mmol})$ in dry THF $(50 \mathrm{~mL})$ over a period of $1 \mathrm{~h}$ under nitrogen atmosphere at room temperature. After being stirred at room temperature for $2 \mathrm{~h}$, half amount of THF was evaporated. To the residue was added $\mathrm{H}_{2} \mathrm{O}(100 \mathrm{~mL})$ and the aqueous layer was extracted with $\mathrm{Et}_{2} \mathrm{O}(80 \mathrm{~mL} \times 3)$. The organic layer was washed with brine and dried over $\mathrm{Na}_{2} \mathrm{SO}_{4}$. The solvent was evaporated and the residue was purified by column chromatography (hexane) to give the exo-methylene compound $\mathbf{1 0}(0.84 \mathrm{~g}, 5.8 \mathrm{mmol}, 85 \%)$ as a colorless oil; IR (neat) $2915(\mathrm{CH}) \mathrm{cm}^{-1}$; ${ }^{1} \mathrm{H}-\mathrm{NMR}\left(500 \mathrm{MHz}, \mathrm{CDCl}_{3}\right) \delta: 2.26$ $(3 \mathrm{H}, \mathrm{s}), 2.79-2.82(2 \mathrm{H}, \mathrm{m}), 2.87-2.89(2 \mathrm{H}, \mathrm{m}), 5.01(1 \mathrm{H}, \mathrm{d}$, $J=1.8 \mathrm{~Hz}), 5.42(1 \mathrm{H}, \mathrm{d}, J=2.3 \mathrm{~Hz}), 7.03(1 \mathrm{H}, \mathrm{d}, J=7.5 \mathrm{~Hz}), 7.12$ $(1 \mathrm{H}, \mathrm{t}, J=7.5 \mathrm{~Hz}), 7.33(1 \mathrm{H}, \mathrm{d}, J=7.4 \mathrm{~Hz}) ;{ }^{13} \mathrm{C}-\mathrm{NMR}(125 \mathrm{MHz}$, $\left.\mathrm{CDCl}_{3}\right) \delta: 18.7,28.8,30.9,102.3,117.9,126.7,128.9,134.6$, 140.8, 145.7, 150.9; MS m/z: $144\left(\mathrm{M}^{+}\right), 115$ (indenyl cation); HR-MS Calcd for $\mathrm{C}_{11} \mathrm{H}_{12}\left(\mathrm{M}^{+}\right)$: 144.0939, Found: 144.0949.

4-Methyl-1-(hydroxymethyl)-2,3-dihydro-1 $H$-inden-1-ol (11) To a mixture of exo-methylene compound $\mathbf{1 0}(1.02 \mathrm{~g}$, $7.1 \mathrm{mmol})$ and $\mathrm{NMO}(1.33 \mathrm{~g}, 11.4 \mathrm{mmol})$ in $\mathrm{CH}_{3} \mathrm{CN}$-acetone- $\mathrm{H}_{2} \mathrm{O}(1: 1: 1,10 \mathrm{~mL})$ was added Os IC-I $\left(1.30 \mathrm{~g}, \mathrm{OsO}_{4}\right.$ $0.36 \mathrm{mmol})$ at room temperature. After being stirred at room temperature for $5 \mathrm{~h}$, Os IC-I was removed by filtration. The Os IC-I was washed with $\mathrm{H}_{2} \mathrm{O}(10 \mathrm{~mL} \times 3)$ and then AcOEt $(10 \mathrm{~mL} \times 3)$. The washed solvents were added to the filtrate. The mixed solution was extracted with AcOEt $(30 \mathrm{~mL} \times 3)$. The organic layer was washed with brine and dried over $\mathrm{Na}_{2} \mathrm{SO}_{4}$. The solvent was evaporated and the residue was purified by column chromatography (hexane-AcOEt $=2: 3$ ) to give the diol $11(1.22 \mathrm{~g}, 6.8 \mathrm{mmol}, 96 \%)$ as a colorless oil; IR (neat) $3422(\mathrm{OH}), 2915(\mathrm{CH}) \mathrm{cm}^{-1}$; ${ }^{1} \mathrm{H}-\mathrm{NMR}(500 \mathrm{MHz}$, $\left.\mathrm{CDCl}_{3}\right) \delta$ : 2.03-2.09 (1H, m), $2.27(3 \mathrm{H}, \mathrm{s}), 2.45$ (1H, ddd, $J=4.0,8.6,13 \mathrm{~Hz}), 2.73(1 \mathrm{H}, \mathrm{ddd}, J=8.0,8.0,16 \mathrm{~Hz}),$, $(1 \mathrm{H}, \mathrm{ddd}, J=4.0,9.2,16 \mathrm{~Hz}), 3.63(1 \mathrm{H}, \mathrm{d}, J=11 \mathrm{~Hz}), 3.73(1 \mathrm{H}$, d, $J=11 \mathrm{~Hz}), 7.10(1 \mathrm{H}, \mathrm{d}, J=7.5 \mathrm{~Hz}), 7.17(1 \mathrm{H}, \mathrm{t}, J=7.5 \mathrm{~Hz})$, $7.23(1 \mathrm{H}, \mathrm{d}, J=7.5 \mathrm{~Hz}) ;{ }^{13} \mathrm{C}-\mathrm{NMR}\left(125 \mathrm{MHz}, \mathrm{CDCl}_{3}\right) \delta: 18.6$, 27.8, 36.5, 68.0, 84.0, 120.7, 127.0, 129.3, 134.3, 142.1, 144.3; MS $m / z: 178\left(\mathrm{M}^{+}\right), 147\left(\left[\mathrm{M}-\mathrm{CH}_{2} \mathrm{OH}\right]^{+}\right), 115$ (indenyl cation); HR-MS Calcd for $\mathrm{C}_{11} \mathrm{H}_{14} \mathrm{O}_{2}\left(\mathrm{M}^{+}\right)$: 178.0994, Found: 178.0969 .

4-Methyl-1-hydroxy-2,3-dihydro-1 $\mathrm{H}$-indene-1-carboxylic Acid (12) A suspension of the diol 11 (1.13 g, $6.3 \mathrm{mmol}$ ), $5 \% \mathrm{Pt} / \mathrm{C}(0.65 \mathrm{~g}), \mathrm{NaHCO}_{3}(1.25 \mathrm{~g}, 14.9 \mathrm{mmol})$ in $\mathrm{H}_{2} \mathrm{O}$-acetone $(5: 1,27 \mathrm{~mL})$ was stirred at $70-80^{\circ} \mathrm{C}$. Oxygen gas was introduced into the reaction mixture for $53 \mathrm{~h}$. The mixture was filtered through a celite pad. The filtrate was extracted with AcOEt to remove non-acidic compound. The aqueous layer was acidified using $2 \mathrm{~mol} / \mathrm{L} \mathrm{H}_{2} \mathrm{SO}_{4}$ to $\mathrm{pH} 2$. Then the acidic solution was extracted with AcOEt $(30 \mathrm{~mL} \times 3)$. The organic layer was washed with brine and dried over $\mathrm{Na}_{2} \mathrm{SO}_{4}$. The solvent was evaporated and the residue was purified by column chromatography (hexane-AcOEt $=3: 7$ ) to give the hydroxycarboxylic acid $12(0.84 \mathrm{~g}, 4.4 \mathrm{mmol}, 69 \%)$ as a colorless oil; IR (neat) $3362(\mathrm{OH}), 2934(\mathrm{CH}), 1712(\mathrm{C}=\mathrm{O}) \mathrm{cm}^{-1} ;{ }^{1} \mathrm{H}-\mathrm{NMR}$ 
$\left(500 \mathrm{MHz}, \mathrm{CDCl}_{3}\right) \delta: 2.26-2.32(1 \mathrm{H}, \mathrm{m}), 2.29(3 \mathrm{H}, \mathrm{s}), 2.78$ (1H, ddd, $J=4.6,8.0,13 \mathrm{~Hz}), 2.96-3.08$ (2H, m), 7.11-7.18 $(3 \mathrm{H}, \mathrm{m}) ;{ }^{13} \mathrm{C}-\mathrm{NMR}\left(125 \mathrm{MHz}, \mathrm{CDCl}_{3}\right) \delta: 18.8,29.1,38.2,84.0$, $120.3,127.3,130.2,134.6,142.4,143.0,180.1 ;$ MS $m / z: 192$ $\left(\mathrm{M}^{+}\right), 147\left([\mathrm{M}-\mathrm{COOH}]^{+}\right), 115$ (indenyl cation); HR-MS Calcd for $\mathrm{C}_{11} \mathrm{H}_{12} \mathrm{O}_{3}\left(\mathrm{M}^{+}\right)$: 192.0786, Found: 192.0777.

Methyl 4-Methyl-1-hydroxy-2,3-dihydro- $1 H$-indene-1-carboxylate (13) To a solution of the acid $12(0.82 \mathrm{~g}, 4.3 \mathrm{mmol})$ in $\mathrm{MeOH}(25 \mathrm{~mL})$ was added $\mathrm{H}_{3} \mathrm{BO}_{3}(81 \mathrm{mg}, 1.3 \mathrm{mmol})$ at room temperature. After being stirred at room temperature for $72 \mathrm{~h}$, saturated aqueous $\mathrm{NaHCO}_{3}$ solution $(40 \mathrm{~mL})$ and $\mathrm{H}_{2} \mathrm{O}(80 \mathrm{~mL})$ were added to the reaction mixture. The solution was extracted with AcOEt $(30 \mathrm{~mL} \times 3)$. The organic layer was washed with brine and dried over $\mathrm{Na}_{2} \mathrm{SO}_{4}$. The solvent was evaporated and the residue was purified by column chromatography (hexane-AcOEt $=3: 2)$ to give the ester $13(0.72 \mathrm{~g}, 3.5 \mathrm{mmol}, 81 \%)$ as a colorless oil; IR (neat) $3457(\mathrm{OH}), 2954(\mathrm{CH}), 1726(\mathrm{C}=$ O) $\mathrm{cm}^{-1}$; ${ }^{1} \mathrm{H}-\mathrm{NMR}\left(500 \mathrm{MHz}, \mathrm{CDCl}_{3}\right) \delta: 2.24-2.30(1 \mathrm{H}, \mathrm{m})$, $2.29(3 \mathrm{H}, \mathrm{s}), 2.70(1 \mathrm{H}, \mathrm{ddd}, J=4.4,8.6,14 \mathrm{~Hz}), 2.95(1 \mathrm{H}, \mathrm{ddd}$, $J=7.5,7.5,16 \mathrm{~Hz}), 3.05(1 \mathrm{H}, \mathrm{ddd}, J=4.4,9.2,16 \mathrm{~Hz}), 3.74(3 \mathrm{H}$, s), $3.82(1 \mathrm{H}, \mathrm{s}), 7.07(1 \mathrm{H}, \mathrm{d}, J=7.4 \mathrm{~Hz}), 7.12(1 \mathrm{H}, \mathrm{d}, J=6.9 \mathrm{~Hz})$, $7.16(1 \mathrm{H}, \mathrm{t}, J=7.4 \mathrm{~Hz}) ;{ }^{13} \mathrm{C}-\mathrm{NMR}\left(125 \mathrm{MHz}, \mathrm{CDCl}_{3}\right) \delta: 18.9$, 29.2, 38.3, 53.2, 84.1, 120.4, 127.3, 130.0, 134.6, 143.0, 143.3, 176.5; MS m/z: $206\left(\mathrm{M}^{+}\right), 147\left([\mathrm{M}-\mathrm{COOMe}]^{+}\right), 115$ (indenyl cation); HR-MS Calcd for $\mathrm{C}_{12} \mathrm{H}_{14} \mathrm{O}_{3}\left(\mathrm{M}^{+}\right)$: 206.0943, Found: 206.0945 .

Methyl 4-Methyl-1-fluoroindan-1-carboxylate (8) (4-MeFICA Me Ester) To a solution of the ester $13(100 \mathrm{mg}$, $0.49 \mathrm{mmol})$ in dry $\mathrm{CH}_{2} \mathrm{Cl}_{2}(3 \mathrm{~mL})$ was added slowly Deoxofluor $(320 \mathrm{mg}, 1.45 \mathrm{mmol})$ in dry $\mathrm{CH}_{2} \mathrm{Cl}_{2}(7 \mathrm{~mL})$ at room temperature under nitrogen atmosphere. After being stirred at room temperature for $3 \mathrm{~h}$, saturated aqueous $\mathrm{NaHCO}_{3}$ solution $(6 \mathrm{~mL})$ and $\mathrm{H}_{2} \mathrm{O}(6 \mathrm{~mL})$ were added to the reaction mixture. The solution was extracted with $\mathrm{CH}_{2} \mathrm{Cl}_{2}(6 \mathrm{~mL})$. The organic layer was washed with brine and dried over $\mathrm{Na}_{2} \mathrm{SO}_{4}$. The sol- vent was evaporated and the residue was purified by column chromatography (hexane-AcOEt $=1: 9$ ) to give the fluoroester $8(79 \mathrm{mg}, 0.37 \mathrm{mmol}, 76 \%)$ as a colorless solid. Recrystallization of 8 from hexane gave colorless needles; $\mathrm{mp} 54.2-55.0^{\circ} \mathrm{C}$; IR (neat) $2949(\mathrm{CH}), 1748(\mathrm{C}=\mathrm{O}) ;{ }^{1} \mathrm{H}-\mathrm{NMR}\left(500 \mathrm{MHz}, \mathrm{CDCl}_{3}\right)$ $\delta: 2.30(3 \mathrm{H}, \mathrm{s}), 2.50(1 \mathrm{H}, \mathrm{dddd}, J=4.6,8.6,13,19 \mathrm{~Hz}), 2.84$ $(1 \mathrm{H}$, dddd, $J=5.2,8.6,13,23 \mathrm{~Hz}), 2.99(1 \mathrm{H}, \mathrm{m}), 3.09(1 \mathrm{H}, \mathrm{m})$, $3.81(3 \mathrm{H}, \mathrm{s}), 7.20(1 \mathrm{H}, \mathrm{d}, J=5.2 \mathrm{~Hz}), 7.21(1 \mathrm{H}, \mathrm{d}, J=5.2 \mathrm{~Hz})$, $7.24(1 \mathrm{H}, \mathrm{t}, J=5.2 \mathrm{~Hz}) ;{ }^{13} \mathrm{C}-\mathrm{NMR}\left(125 \mathrm{MHz}, \mathrm{CDCl}_{3}\right) \delta: 18.8$, 28.9, $35.8\left(\mathrm{~d}, J=24.0 \mathrm{~Hz}, \mathrm{CH}_{2}\right), 52.7,102.4(\mathrm{~d}, J=190.7 \mathrm{~Hz}, \mathrm{C})$, 121.4, 127.4, 131.2, 134.6, 138.8 (d, $J=21.6 \mathrm{~Hz}, \mathrm{C}), 143.9,171.2$ (d, $J=32.4 \mathrm{~Hz}, \mathrm{C}) ;{ }^{19} \mathrm{~F}-\mathrm{NMR}\left(470 \mathrm{MHz}, \mathrm{CDCl}_{3}\right) \delta:-137.9(\mathrm{t}$, $J=22 \mathrm{~Hz})$; MS m/z: $208\left(\mathrm{M}^{+}\right), 149\left([\mathrm{M}-\mathrm{COOMe}]^{+}\right), 115$ (indenyl cation); HR-MS Calcd for $\mathrm{C}_{12} \mathrm{H}_{13} \mathrm{O}_{2} \mathrm{~F}\left(\mathrm{M}^{+}\right)$: 208.0900, Found: 208.0891; Anal. Calcd for $\mathrm{C}_{12} \mathrm{H}_{13} \mathrm{O}_{2} \mathrm{~F}$ : C, 69.22; H, 6.29. Found: C, 69.16; H, 6.20.

\section{References and Note}

1) Takahashi T., Kameda H., Kamei T., Ishizaki M., J. Fluor. Chem., 127, 760-768 (2006).

2) Takahashi T., Kameda H., Kamei T., Koyanagi J., Pichierri F., Omata K., Ishizaki M., Nakamura H., Tetrahedron Asymmetry, 24, 1001-1009 (2013)

3) Seco J. M., Quiñoá E., Riguera R., Chem. Rev., 104, 17-117 (2004).

4) Wako Pure Chemical Industries, Ltd., Wako Organic Square, 16, 8 (2006).

5) Ainge D., Ennis D., Gidlund M., Stefinovic M., Vaz L. M., Org. Process Res. Dev., 7, 198-201 (2003).

6) Schlosser et al. reported that the decarboxylated compound was mainly obtained by fluorination of $\alpha$-hydroxycarboxylic acid: Schlosser M., Michel D., Guo Z. W., Sih C. J., Tetrahedron, 52, 8257-8262 (1996).

7) Houston T. A., Wilkinson B. L., Blanchfield J. T., Org. Lett., 6, 679-681 (2004)

8) Lal G. S., Pez G. P., Pesaresi R. J., Prozonic F. M., Cheng H., J. Org. Chem., 64, 7048-7054 (1999). 